\section{The antecedents of perceived value in the Airbnb context}

\author{
Aubrey Stollery
}

Keimyung University, Daegu, Republic of Korea, and

Soo Hyun Jun

College of Business Administration, Department of Tourism Management, Keimyung University, Daegu, Republic of Korea

\begin{abstract}
Purpose - This study aims to examine the antecedents of perceived value in the Airbnb context using the variables of perceived benefits (i.e. monetary saving, hedonic benefit, novelty and social interaction) and perceived risks (i.e. performance, physical, psychological and time).

Design/methodology/approach - The study population was Airbnb users in South Korea. This study applied a survey research method using a questionnaire. A link to the survey was sent via e-mail to panel members of a multinational research company.

Findings - The results revealed the positive influence of monetary saving, hedonic benefit and novelty on perceived value and the negative influence of psychological risk on perceived value.

Research limitations/implications - The results of this study, which identified the specific factors that influence Airbnb users' perception of value, can assist Airbnb managers and Airbnb hosts in developing appropriate marketing plans and strategies to enhance the value of their offerings.

Originality/value - This study provided empirical support to the inclusion of affective factors and risk in determining perceived value. Moreover, while previous Airbnb studies focused on consumers from Western countries (e.g. USA and Canada), this study used a sample of South Korean consumers.
\end{abstract}

Keywords Perceived benefits, Perceived value, Airbnb, Sharing economy, Perceived risks

Paper type Research paper

\section{Introduction}

The concept of perceived value has long been used by researchers and marketers to understand the purchase decision-making behavior of consumers. Many studies have shown that perceived value influences consumer behavior such as purchase intentions (Bajs, 2015; Cronin et al., 2000; Oh, 2000; Petrick, 2004). Although the literature is clear in indicating the consequences of perceived value, its antecedents have not been as well developed (Zauner et al., 2015). One explanation for this could be that the factors that influence perceived value can change depending on the context (Chen and Dubinsky, 2003). Gallarza et al. (2011) also suggested that the factors which affect perceived value are determined by the product or service being studied. Thus, it is important that research should be conducted to identify the antecedents of perceived value in different contexts.

(C) Aubrey Stollery and Soo Hyun Jun. Published in the Asia Pacific Journal of Innovation and Entrepreneurship. Published by Emerald Publishing Limited. This article is published under the Creative Commons Attribution (CC BY 4.0) licence. Anyone may reproduce, distribute, translate and create derivative works of this article (for both commercial and non-commercial purposes), subject to full attribution to the original publication and authors. The full terms of this licence may be seen at http://creativecommons.org/licences/by/4.0/legalcode
Antecedents of perceived value in Airbnb

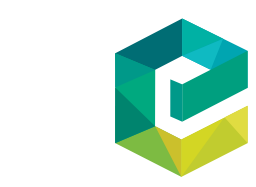

Asia Pacific Journal of Innovation and Entrepreneurship Vol. 11 No. 3, 2017 pp. $391-404$ pp. $391-404$
Emerald Publishing Limited 2071-1395 DOI 10.1108/APJE-12-2017-040 
Petrick (2004, p. 29) suggested that a better understanding of the antecedents of perceived value would enable managers to "cater experiences to their various markets in a way to maximize perceptions of value and inevitably future purchase behaviors".

This study focuses on the context of the sharing economy, specifically Airbnb. Airbnb is an online platform that connects travelers looking for a place to stay, with people that have space to rent out (Guttentag, 2015). Since 2008, Airbnb has served around 150 million guests and offers more than three million listings (i.e. spaces available for rent) in 191 countries (Airbnb, 2017). Given that industry reports predict the number of Airbnb users to continue rising (Ting, 2017; Verhage, 2016), it seems ideal and timely to identify and understand the factors that contribute to the perception of value among Airbnb users.

Accordingly, the aim of this study is to examine the antecedents of perceived value in the Airbnb context. As noted earlier, the factors that may affect perceived value are contextdependent. Hence, this study seeks to analyze the variables that have been identified in the literature as associated with the use of the sharing economy and Airbnb. Specifically, we propose a model of perceived value using perceived benefits (i.e. gains from use of a product or service) and perceived risks (i.e. potential loss from use of a product or service) as antecedents in the Airbnb context. In addition, this study focuses on a sample of South Korean consumers as travelers from Asian countries using Airbnb are gradually increasing (Iyer, 2014). For instance, Asian travelers make up seven of the top ten countries that visited Japan using Airbnb with the most users coming from South Korea (Nikkei Asian Review, 2016). Findings from this study will assist Airbnb managers and Airbnb hosts develop appropriate strategies to enhance the value of their offering.

\section{Literature review}

\section{Perceived value}

Perceived value has been defined in various ways within the literature. For instance, Woodruff (1997, p. 142) referred to it as:

[...] a customer's perceived preference for and evaluation of those product attributes, attribute performances, and consequences arising from use that facilitate (or block) achieving the customer's goals and purposes in use situations.

whereas Chen and Dubinsky (2003, p. 326) described it as "a consumer's perception of the net benefits gained in exchange for the costs incurred in obtaining the desired benefits". However, the most commonly cited definition of perceived value is from Zeithaml (1988, p. 14) - "the consumer's overall assessment of the utility of a product based on perceptions of what is received and what is given".

The value concept has been suggested as theoretically based on the utility theory of microeconomics (Sanchez-Fernandez and Iniesta-Bonillo, 2006). One application of the utility theory is the weighing of pros and cons of the alternatives to help decision makers determine the "best" (most preferred) course of action for the situation (Fishburn, 1968). Scholars generally conceptualize perceived value in the same way - a trade-off between benefits or what the consumer receives and sacrifices or what the consumer gives up (Chen and Dubinsky, 2003; Woodruff, 1997). Zeithaml (1988) proposed that the benefit component of value is composed of intrinsic attributes, extrinsic attributes, perceived quality and other relevant high level abstraction, whereas the sacrifice component is composed of monetary prices and nonmonetary price (e.g. time, energy and effort). It is assumed that the benefit component has a positive influence on perceived value and that the sacrifice component has a negative influence (Bajs, 2015; Gallarza and Gil Saura, 2006). 
Early studies on perceived value were based on a cognitive perspective. That is, these studies have mainly used quality and price as antecedents of perceived value (SanchezFernandez and Iniesta-Bonillo, 2006; Sweeney et al., 1999), which led to a value-for-money conceptualization (Sweeney and Soutar, 2001). However, this had been suggested as being too simple (Bolton and Drew, 1991; Sweeney and Soutar, 2001) and may force consumers to assess tourism services more on their functional and utilitarian dimensions (Otto and Ritchie, 1996).

Recent studies, however, have taken a broader approach by incorporating affective

Antecedents of perceived value in Airbnb components and non-monetary costs such as effort and risks. For example, Gallarza and Gil Saura (2006) used the factors of efficiency, play, aesthetics, social value, perceived risk and time and effort spent in a travel-behavior context. Sparks et al. (2008) applied relaxation, gift, status, flexibility, fun and new experience as dimensions of value in the timeshare industry. The inclusion of affective factors has been argued as more appropriate due to the importance of experiential aspects in consumption (Holbrook and Hirschman, 1982) especially in tourism (Otto and Ritchie, 1996).

Following the suggestion that perceived value is context-dependent, the specific antecedents examined in this study are based on factors associated with the use of the sharing economy and Airbnb. Specifically, factors that consumers may gain or lose when using sharing economy services and Airbnb are taken into consideration. A review of the current literature reveals factors that are grouped as perceived benefits and perceived risks.

\section{Perceived benefits}

Benefit is defined as the advantages enjoyed by the consumer from the use of a product or service (Gutman, 1982). In an online context, Forsythe et al. (2006) referred to perceived benefit as the consumer's subjective perception of gain. On the basis of existing literature (Carlson Wagonlit Travel, 2015; Folger, 2016; Guttentag, 2015; Tussyadiah and Pesonen, 2016), we suggest that benefits associated with Airbnb use are monetary saving, hedonic benefit, novelty and social interaction.

Monetary saving refers to spending less and saving money (Mimouni-Chaabane and Volle, 2010). Tussyadiah and Pesonen (2016) indicate that use of peer-to-peer accommodations (e.g. Airbnb) is driven by its lower costs in comparison to hotels. This reduced cost allows guests to save money (Folger, 2016). Moreover, Finley (2013) reported that compared to using traditional accommodations, Airbnb users feel they obtain more value from the Airbnb experience as they are able to get a better place for a lower price.

Hedonic benefit relates to the need for enjoyment, fun or pleasure during consumption (Lai, 1995). As argued by Holbrook and Hirschman (1982), consumption is not only limited to solving a problem but also includes seeking fun, amusement and enjoyment. Bellotti et al. (2015) indicated that users of sharing economy services are attracted to experiences that are interesting, engaging and amusing. PricewaterhouseCoopers (2015) also reported that consumers think it is fun participating in the sharing economy. In addition, the study of Satama (2014) found that hedonic motivations have a positive influence in the adoption of Airbnb.

Novelty is generally viewed as the difference between the past and present experience of an individual (Lee and Crompton, 1992; Pearson, 1970). According to Hirschman (1980), the concept of novelty has two related aspects: the first aspect related to searching for new information, and the second aspect related to searching for variety. Several authors (Kim et al., 2012; Petrick, 2002) also related this concept to uniqueness. For the purpose of this study, novelty refers to doing or experiencing something new, different and unique. A desire for novelty is one of the frequently reported motives for travel (Lee and Crompton, 1992). 
APJIE 11,3

According to Tussyadiah and Pesonen (2016), novelty is present to a certain degree when using peer-to-peer accommodations (e.g. Airbnb). Moreover, they suggested that travelers looking for variety in their experiences may be attracted to peer-to-peer accommodations because they are located outside of the usual tourist areas.

Social interaction refers to a feeling of connection and group identity with local people (Kim et al., 2012). One of the motivations in pleasure travel is the desire to connect with local people (Crompton, 2004). According to Williams and Soutar (2009), interaction with other people creates social benefit in the tourism context. As Airbnb accommodations are homes of ordinary people, it gives travelers the opportunity to interact with the host or neighbors (Guttentag, 2015). Bellotti et al. (2015) suggested that social connections may be a way to enhance the overall value of sharing economy services that offer accommodations.

\section{Perceived risks}

Stone and Winter (1985, p. 2) defined perceived risk as “one's expectation of loss associated with an exchange". In an online context, Forsythe et al. (2006) refers to perceived risk as the consumer's subjective perception of potential loss. Previous studies on the sharing economy and Airbnb have suggested that consumers perceive risks in terms of performance, physical, psychological and time (Carlson Wagonlit Travel, 2015; Finley, 2013; Folger, 2016; Guttentag, 2015; Mun, 2013).

Performance risk is defined as the possibility of not getting what is expected or the service not performing as expected (Horton, 1976). This risk may be a result of consumers' limited ability to accurately determine the quality of offerings online as it cannot be touched, felt or tried beforehand (Forsythe and Shi, 2003). Mun (2013) indicated that there were some worries about the quality and misrepresentation of what was being offered in the sharing economy. In the case of Airbnb, this may translate to the photos, location and description of the listings posted online not matching the ones in real life (Finley, 2013). Furthermore, as there are no specific hospitality standards implemented among Airbnb listings, risks were also noted regarding cleanliness and noise levels (Finley, 2013; Guttentag, 2015).

Physical risk refers to "the chances that (brand) may not be safe, may be (or become) harmful or injurious to health" (Jacoby and Kaplan, 1972, p.11). Compared to hotels or traditional bed and breakfasts, Airbnb listings are unregulated (Stone, 2015), and there seems to be no health and safety regulations that they have to follow (Bonnington, 2015). As such, security and personal safety is one of the concerns in the use of Airbnb (Carlson Wagonlit Travel, 2015; Finley, 2013). Additionally, several "horror" stories in the use of Airbnb exist online. There was a host who locked a guest in and sexually assaulted him (Lieber, 2015) and another who drugged his guests (Jose, 2013). In 2013, a Canadian woman died in an Airbnb listing in Taiwan as it had a broken heater which filled the room with poisonous gas (Hill, 2015).

Psychological risk refers to the possibility that using Airbnb will have a negative effect on a person's peace of mind (Garner, 1986). Psychological risks are dominant in purchase situations, wherein the item or service is expensive, complex and difficult to judge (Kim et al., 2009; Stone and Grønhaug, 1993). The study of Pires et al. (2004) found that psychological risks were ranked the highest for services purchased online. As there are no hospitality standards implemented among Airbnb listings and guests do not know what to expect, it becomes troubling for users (Finley, 2013).

Time risk means the possibility of wasting time, taking too much time or effort in using a service (Garner, 1986). Mitchell and Greatorex (1993) found that for hotel services, time risk was the second most important risk for consumers. In the case of Airbnb, as they provide a wide variety of accommodation choices, it may be time-consuming looking for offers that are 
trustworthy (Carlson Wagonlit Travel, 2015). Additionally, as not all Airbnb listings have an instant book feature, it would require more time and effort to send messages to the host before being able to reserve a room (Guttentag, 2015).

\section{Hypotheses}

Several studies in different contexts provide support for the positive relationship between the specific benefits used in this study and perceived value. Han and Hwang (2013), in their study of medical hotels, found that financial saving was a significant predictor of perceived value. In a cruise services context, Duman and Mattila (2005) showed the strong positive relationship between hedonics and perceived value. Sparks et al. (2008) reported that timeshare owners acquired value from novelty (operationalized in their study as new experiences). In the travel context, Gallarza and Gil Saura (2006) showed that social interaction (operationalized in their study as social value) was a positive antecedent of perceived value. On the basis of the previous discussion, it is proposed that

H1. Monetary saving positively influences perceived value.

H2. Hedonic benefit positively influences perceived value.

H3. Novelty positively influences perceived value.

H4. Social interaction positively influences perceived value.

Several scholars (Agarwal and Teas, 2001; Zauner et al., 2015) have suggested that perceived risk is a variable that may affect consumers' value perception. Day and Crask (2000, p. 57) also proposed a relationship between perceived value and risk as this will reframe value "in terms consistent with the manner in which consumers evaluate and choose among alternatives". Furthermore, they posit that when risk is reduced, value is provided to the consumer.

Some empirical studies (Chen and Dubinsky, 2003; Kwun and Oh, 2004) have already been conducted to analyze the relationship between perceived risk and value. However, most of these studies have mainly used a general risk measure in their model. Only a few studies have explored the relationship between the individual dimensions of risk and perceived value. For example, the study of Sweeney et al. (1999) and Agarwal and Teas (2001) used performance and financial risks. They found that performance and financial risks have a negative effect on perceived value. The present study proposes the same negative effect as risks represent the sacrifice component of value. Accordingly, it is hypothesized that

H5. Performance risk negatively influences perceived value.

H6. Physical risk negatively influences perceived value.

H7. Psychological risk negatively influences perceived value.

H8. Time risk negatively influences perceived value.

\section{Methodology}

The target population of this study was Airbnb users in South Korea. The study sample was drawn from the panel of a multinational research company. Data were gathered by means of a questionnaire. The questionnaire was distributed online to panel members through e-mail messages that contained a link to the survey. There were a total of 4,688 panel members
Antecedents of perceived value in Airbnb 
APJIE 11,3 invited to participate in the study. On the basis of a filter question, only panel members who had previous Airbnb use experience were included in the final sample.

In developing the questionnaire, items were adopted from scales used by previous researchers and modified to fit the Airbnb context. Four items under monetary saving (i.e. lowers my travel costs, saves me money, makes travel more affordable and benefits me financially), five items under hedonic benefit (i.e. exciting, enjoyable, fun, interesting and pleasant) and four items under social interaction (i.e. know people from the local neighborhoods, develop social relationships, connect with locals and have a meaningful interaction with locals) were from the study of Tussyadiah (2016). To measure novelty, six items (i.e. different types of accommodations, various experiences, wide assortment of experiences, new places, new experiences and innovativeness) were adopted and modified from Vogt and Fesenmaier (1998) and four items (unique places, something one-of-a-kind, unusual places and unique experiences) came from Folger (2016) and the Airbnb website. Four items in the performance risk scale (not matching the photos posted online, not matching the descriptions posted online, would not be clean and host would treat me unkindly) were developed from the study of Finley (2013), Folger (2016), Guttentag (2015) and Mun (2013). To form the scale for physical risk, items (i.e. something bad happening, host may do something bad and may not be safe staying at an Airbnb place) were taken from Jose (2013), Lieber (2015) and Stone (2015). Psychological risk items (i.e. feeling of unwanted anxiety, feeling psychologically uncomfortable and experiencing unnecessary tension) were from Kim et al. (2009). Four items to measure time risk (i.e. waste of time, a lot of effort, take too much time and inefficient use of time) were from the study of Guttentag (2015) and Kim et al. (2009). Perceived value was measured using a three-item scale (i.e. The Airbnb experience has satisfied my wants, Overall, the value of the Airbnb experiences is high, Compared to what I gave up, what I received from Airbnb was high) from Gallarza and Gil Saura (2006). All responses to the items were measured using a seven-point Likert type scale with "1" being "strongly disagree" and "7" being "strongly agree". Demographic information and Airbnb use behavior of the respondents were also collected.

\section{Results}

Out of 4,688 panel members who were invited to participate in the study, 1,393 members responded, which represents a 29.7 per cent response rate. The filter question that was included to select Airbnb users only resulted in the collection of 416 complete responses. After data cleaning, six responses were removed due to the use of similar internet protocol (IP) address, leading to a total of 410 responses being used for further analysis.

Table I presents the demographic profile and Airbnb use behavior of the respondents. The respondents were predominantly female (65.6 per cent). Nearly half (44.9 per cent) of the respondents were aged between 20 and 29 years. Most of the respondents ( 70.0 per cent) had a university or college degree and the highest number of respondents came from Seoul (44.9 per cent). Almost half of the respondents found out about Airbnb from the internet (44.6 per cent). During their most recent Airbnb use, 41.2 per cent of the respondents stayed in Asia (excluding South Korea). In terms of the number of Airbnb use, 27.8 per cent of the respondents have used it twice, while 26.8 per cent of the respondents have used it four times or more.

The data were factor-analyzed using principal component analysis with Varimax rotation. Table II summarizes the results of the factor and reliability analyses. Four factors emerged for both perceived benefits and perceived risks, which explained 75.024 and 84.613 


\begin{tabular}{|c|c|c|c|}
\hline Characteristics & Frequency & $(\%)$ & $\begin{array}{l}\text { Antecedents of } \\
\text { nerceived }\end{array}$ \\
\hline $\begin{array}{l}\text { Gender } \\
\text { Male } \\
\text { Female }\end{array}$ & $\begin{array}{l}141 \\
269\end{array}$ & $\begin{array}{l}34.4 \\
65.6\end{array}$ & $\begin{array}{l}\text { value in } \\
\text { Airbnb }\end{array}$ \\
\hline $\begin{array}{l}\text { Age } \\
20-29 \\
30-39 \\
40-49 \\
50-59\end{array}$ & $\begin{array}{r}184 \\
125 \\
77 \\
24\end{array}$ & $\begin{array}{r}44.9 \\
30.5 \\
18.8 \\
5.9\end{array}$ & 397 \\
\hline $\begin{array}{l}\text { Level of education } \\
\text { High school graduate } \\
\text { University/college graduate } \\
\text { Masters or PhD graduate } \\
\text { Others }\end{array}$ & $\begin{array}{r}48 \\
287 \\
75 \\
-\end{array}$ & $\begin{array}{c}11.7 \\
70.0 \\
18.3 \\
-\end{array}$ & \\
\hline $\begin{array}{l}\text { Monthly household income } \\
\text { under \$ } 2,000,000 \\
\$ 2,000,001 \text { to } 4,000,000 \\
\$ 4,000,001 \text { to } 6,000,000 \\
\$ 6,000,001 \text { to } 8,000,000 \\
\$ 8,000,001 \text { to } 10,000,000 \\
\text { \$ } 10,000,001 \text { and over }\end{array}$ & $\begin{array}{r}25 \\
105 \\
102 \\
94 \\
54 \\
30\end{array}$ & $\begin{array}{r}6.1 \\
25.6 \\
24.9 \\
22.9 \\
13.2 \\
7.3\end{array}$ & \\
\hline $\begin{array}{l}\text { Place of residence } \\
\text { Seoul } \\
\text { Incheon, Gyeonggi } \\
\text { Busan, Gyeongnam } \\
\text { Daegu, Gyeongbuk } \\
\text { Daejeon, Chungcheong, Gangwon } \\
\text { Gwangju, Jeolla, Jeju }\end{array}$ & $\begin{array}{r}184 \\
113 \\
48 \\
30 \\
18 \\
17\end{array}$ & $\begin{array}{r}44.9 \\
27.6 \\
11.7 \\
7.3 \\
4.4 \\
4.1\end{array}$ & \\
\hline $\begin{array}{l}\text { How they found out about Airbnb } \\
\text { Internet } \\
\text { Friends and acquaintances } \\
\text { Homepage (www.airbnb.com) } \\
\text { SNS } \\
\text { Mobile app } \\
\text { TV or radio } \\
\text { Others }\end{array}$ & $\begin{array}{r}183 \\
133 \\
50 \\
20 \\
14 \\
9 \\
1\end{array}$ & $\begin{array}{r}44.6 \\
32.4 \\
12.2 \\
4.9 \\
3.4 \\
2.2 \\
0.2\end{array}$ & \\
\hline $\begin{array}{l}\text { Area recently stayed at using Airbnb } \\
\text { Asia (except South Korea) } \\
\text { South Korea } \\
\text { Europe } \\
\text { North America } \\
\text { Oceania } \\
\text { South America }\end{array}$ & $\begin{array}{r}169 \\
100 \\
100 \\
33 \\
5 \\
3\end{array}$ & $\begin{array}{r}41.2 \\
24.4 \\
24.4 \\
8.0 \\
1.2 \\
0.7\end{array}$ & \\
\hline $\begin{array}{l}\text { Number of Airbnb use } \\
\text { Twice } \\
\text { Four times or more } \\
\text { Once } \\
\text { Thrice }\end{array}$ & $\begin{array}{r}114 \\
110 \\
106 \\
80\end{array}$ & $\begin{array}{l}27.8 \\
26.8 \\
25.9 \\
19.5\end{array}$ & $\begin{array}{r}\text { Table I. } \\
\text { Demographic profile } \\
\text { and Airbnb use } \\
\text { behavior of } \\
\text { respondents }\end{array}$ \\
\hline
\end{tabular}




\section{APJIE \\ 11,3}

398

\begin{tabular}{|c|c|c|c|c|c|}
\hline Factor & Items & Factor loading & Eigenvalue & Variance (\%) & Alpha \\
\hline \multirow[t]{4}{*}{ Monetary saving } & MS2 & 0.835 & \multirow[t]{4}{*}{3.213} & \multirow[t]{4}{*}{16.066} & \multirow[t]{4}{*}{0.894} \\
\hline & MS1 & 0.832 & & & \\
\hline & MS3 & 0.817 & & & \\
\hline & MS4 & 0.737 & & & \\
\hline \multirow[t]{5}{*}{ Hedonic benefit } & HB2 & 0.807 & \multirow[t]{5}{*}{4.024} & \multirow[t]{5}{*}{20.118} & \multirow[t]{5}{*}{0.937} \\
\hline & HB1 & 0.804 & & & \\
\hline & HB4 & 0.796 & & & \\
\hline & HB3 & 0.774 & & & \\
\hline & HB5 & 0.751 & & & \\
\hline \multirow[t]{7}{*}{ Novelty } & N6 & 0.763 & \multirow[t]{7}{*}{4.275} & \multirow[t]{7}{*}{21.376} & \multirow[t]{7}{*}{0.914} \\
\hline & N3 & 0.749 & & & \\
\hline & N7 & 0.720 & & & \\
\hline & N5 & 0.691 & & & \\
\hline & N4 & 0.665 & & & \\
\hline & $\mathrm{N} 2$ & 0.664 & & & \\
\hline & N1 & 0.625 & & & \\
\hline \multirow[t]{5}{*}{ Social interaction } & SI3 & 0.886 & \multirow[t]{4}{*}{3.493} & \multirow[t]{4}{*}{17.464} & \multirow[t]{4}{*}{0.902} \\
\hline & SI4 & 0.877 & & & \\
\hline & SI2 & 0.816 & & & \\
\hline & SI1 & 0.676 & & & \\
\hline & $\mathrm{KMO}=0.932$ & rtlett's $\chi^{2}=6771$ & Total variance & $5.024 \%$ & \\
\hline \multirow[t]{4}{*}{ Performance risk } & PR2 & 0.894 & \multirow[t]{4}{*}{3.348} & \multirow[t]{4}{*}{23.916} & \multirow[t]{4}{*}{0.906} \\
\hline & PR1 & 0.880 & & & \\
\hline & PR3 & 0.866 & & & \\
\hline & PR4 & 0.748 & & & \\
\hline \multirow[t]{3}{*}{ Physical risk } & PHYR2 & 0.842 & \multirow[t]{3}{*}{2.336} & \multirow[t]{3}{*}{16.687} & \multirow[t]{3}{*}{0.914} \\
\hline & PHYR3 & 0.816 & & & \\
\hline & PHYR1 & 0.727 & & & \\
\hline \multirow[t]{3}{*}{ Psychological risk } & PSYR1 & 0.829 & \multirow[t]{3}{*}{2.516} & 17.971 & 0.932 \\
\hline & PSYR2 & 0.825 & & & \\
\hline & PSYR3 & 0.805 & & & \\
\hline Time risk & TR3 & 0.871 & 3.646 & 26.039 & 0.946 \\
\hline & TR2 & 0.865 & & & \\
\hline & TR1 & 0.864 & & & \\
\hline & TR4 & 0.864 & & & \\
\hline & $\mathrm{KMO}=0.894$ & rtlett's $\chi^{2}=5446$ & Total variance & $4.613 \%$ & \\
\hline Perceived value & PV3 & 0.876 & 2.188 & 72.945 & 0.809 \\
\hline & PV1 & 0.859 & & & \\
\hline & PV2 & 0.827 & & & \\
\hline & $\mathrm{KMO}=0.70$ & rtlett's $\chi^{2}=424.0$ & Total variance & $.945 \%$ & \\
\hline
\end{tabular}

Table II.

\section{Results of}

exploratory factor analysis and reliability analysis per cent of the variance, respectively. Except for three items under perceived benefits, all items loaded on their intended factor. These three items were removed and excluded from further analysis. All factor loading scores were 0.60 and higher, while the Cronbach's alpha scores for all factors were equal to or greater than 0.80 .

The hypotheses were tested with a regression model using the enter method. The dependent variable, perceived value was regressed against the factors that emerged from the factor analysis. Multicollinearity was not a concern for the data as the variance inflation factor (VIF) values were all below the cut-off value of 5 (Hair et al., 2011). Table III reports the results of the regression analysis. With an adjusted $R^{2}$ value of 0.437 , this model accounts for 43.7 per cent of the variance in perceived value. 


\begin{tabular}{|c|c|c|c|c|}
\hline & Beta & & $t$ & \\
\hline $\begin{array}{l}\text { Perceived benefits } \\
\text { Monetary saving } \\
\text { Hedonic benefit } \\
\text { Novelty } \\
\text { Social interaction } \\
\text { Perceived risks } \\
\text { Performance risk } \\
\text { Physical risk } \\
\text { Psychological risk } \\
\text { Time risk } \\
\text { Adjusted } R^{2} \\
\text { ANOVA regression F ratio } \\
\text { Notes: } * p<0.05 ; * *<<0.01 ; * * * p<0.001\end{array}$ & $\begin{array}{r}0.008 \\
0.026 \\
-0.226 \\
0.069\end{array}$ & 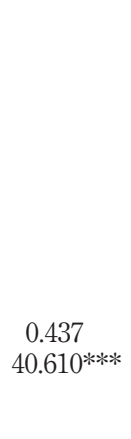 & $\begin{array}{l}2.691 \text { ** } \\
3.082^{* *} \\
5.862^{* * *} \\
1.378 \\
\\
0.173 \\
0.478 \\
-4.064^{* * * *} \\
1.276\end{array}$ & $\begin{array}{l}\text { Table III. } \\
\text { Results of multiple } \\
\text { regression analysis } \\
\text { on perceived value }\end{array}$ \\
\hline
\end{tabular}

In terms of perceived benefits, monetary saving $(\beta=0.128, p<0.01)$, hedonic benefit ( $\beta=$ $0.177, p<0.01)$ and novelty $(\beta=0.353, p<0.001)$ were significantly and positively associated with perceived value. Thus, $H 1, H 2$ and $H 3$ were supported. Unexpectedly, social interaction was not significantly related to perceived value. Therefore, support for $H 4$ was not found.

With regard to perceived risks, only psychological risk $(\beta=-0.226, p<0.001)$ was significantly and negatively associated with perceived value, which lends support for $H 7$. The proposed negative effect of performance risk, physical risk and time risk on perceived value was not found. Thus, $H 5, H 6$ and $H 8$ were not supported.

On the basis of the regression coefficients, novelty had the greatest impact on the perceived value of Airbnb users. This was followed by psychological risk, hedonic benefit and monetary saving.

\section{Conclusion}

The results revealed the significant positive effects of monetary saving, hedonic benefit and novelty on perceived value. These findings suggest that South Korean Airbnb guests find value in using Airbnb because it allows them to have different and unique experiences, have fun and excitement and save money. Novelty was found to be the strongest predictor of perceived value, which implies the importance of providing experiences to guests that are different from the usual. These results support previous studies, which show that affective factors (i.e. hedonics and novelty) influence perceived value (Duman and Mattila, 2005; Sparks et al., 2008). It was also found that social interaction does not influence perceived value despite many studies highlighting this specific benefit in using Airbnb. This result suggests that the opportunity to interact and form relationships with locals does not enhance the value of using Airbnb among South Korean guests.

Results further reveal the significant negative effect of psychological risk on perceived value. This finding is in line with the study of Stone and Grønhaug (1993) and Kim et al. (2009) regarding the presence of psychological risks on items that are complex and hard to judge. This result indicates that guests have feelings of anxiety when using Airbnb, which influences their value perception of the service. The other types of risk (i.e. performance, physical and time) were found to have no influence on perceived value. A possible reason for this result may be attributed to the nature of the 
APJIE 11,3

\section{0}

study sample. Almost 75 per cent of the respondents had used Airbnb twice or more and this experience could have reduced their risk perception. Previous studies have indicated that less risk is perceived as consumers gain more experience (Kim et al., 2009; Sonmez and Graefe, 1998). If this study had been conducted with non-users of Airbnb, the presence of the other risk types might have been more salient. Further studies, however, are needed to support this explanation.

\section{Theoretical and managerial implications}

This study broadens the application of the perceived value concept into the sharing economy context, specifically Airbnb. The results of the study also contribute to the literature by identifying the specific antecedents of perceived value in the Airbnb context. Moreover, it provides empirical support to the inclusion of affective factors as antecedents of perceived value. Specifically, the importance of novelty and hedonics in the Airbnb experience were highlighted in this study despite the focus of the sharing economy and Airbnb literature on the economic aspect. Although this study found that only one risk type (i.e. psychological risk) had a significant effect on perceived value, it implies that it is still worthwhile to include the different risk dimensions as antecedents of perceived value. As this study showed, even if consumers have experience with the service, certain risk types may still be present which can subsequently affect their value perceptions.

The study results also have a significant implication in the management and promotion of Airbnb. The study results indicate the importance of novelty and hedonics to guests of Airbnb. Airbnb management should continue to emphasize the different, unique and fun experiences to be had when using Airbnb in their marketing strategies. Additionally, Airbnb hosts should pay attention on providing guests with experiences that are enjoyable and unusual. It is also important to make guests feel that they are able to save money when they use Airbnb as opposed to using hotels or motels in the area they will be staying at. A key issue to resolve is the presence of psychological risks in the use of Airbnb. A suggestion would be for Airbnb managers and hosts to identify the sources of worry and anxiety for guests and find ways to address them. For example, Airbnb management may provide guarantees to their guests (e.g. by sending an email message and providing contact numbers) that they will be taken care of in case of any eventualities during their stay.

\section{Limitations and future studies}

Several limitations were identified in the study. First, this study is limited to a sample of Airbnb users from one country, South Korea. Therefore, caution must be taken in generalizing the results. Further studies should be undertaken with Airbnb users from different countries to further validate the results. Second, this study only examined the perception of Airbnb users. Additional research is needed to analyze the perceptions of nonusers as the factors that influence their perceived value of Airbnb may be different from those with experience. As mentioned previously, risk perceptions may be more salient for consumers who have no Airbnb use experience. Third, the variables used in the study were limited to the ones identified in the literature as associated with the sharing economy and Airbnb. This model accounted for a significant amount of variance (44 per cent); however, it also indicates that there are other possible antecedents of perceived value in the Airbnb context. Quality and price are two such factors that have been shown to significantly affect value perceptions but were not included in this study. Hence, future research should include price, quality and other variables in their model of perceived value. Finally, while this study 
is exploratory in nature and applied regression analysis, future studies are encouraged to apply a more powerful statistical approach for a richer understanding of the antecedents and additionally the consequences (e.g. intention and repurchase intention) of perceived value.

\section{References}

Agarwal, S. and Teas, R.K. (2001), "Perceived value: mediating role of perceived risk", Journal of Marketing Theory \& Practice, Vol. 9 No. 4, pp. 1-14.

Airbnb (2017), About Us, available at: www.airbnb.com/about/about-us (accessed 28 April 2017).

Bajs, I.P. (2015), "Tourist perceived value, relationship to satisfaction, and behavioral intentions: the example of the Croatian tourist destination Dubrovnik", Journal of Travel Research, Vol. 54 No. 1, pp. 122-134.

Bellotti, V., Ambard, A., Turner, D., Gossmann, C., Demkova, K. and Carroll, J.M. (2015), "A muddle of models of motivation for using peer-to-peer economy systems", paper presented at the ACM Conference on Human Factors in Computing Systems, (18-23 April), Seoul, available at: www. researchgate.net/publication/275653007_A_Muddle_of_Models_of_Motivation_for_Using_Peer-toPeer_Economy_Systems (accessed 7 October 2016).

Bolton, R.N. and Drew, J.H. (1991), "A multistage model of customers' assessments of service quality and value", Journal of Consumer Research, Vol. 17 No. 4, pp. 375-384.

Bonnington, C. (2015), “The tragic Airbnb problem you've probably never thought about", available at: www.refinery29.com/2015/11/97263/airbnb-safety-regulation-controversy (accessed 6 June 2016).

Carlson Wagonlit Travel (2015), "Faster, Smarter, Better?", available at: www.cwtinsights.com/ (accessed 7 March 2016).

Chen, Z. and Dubinsky, A.J. (2003), "A conceptual model of perceived customer value in e-commerce: a preliminary investigation”, Psychology and Marketing, Vol. 20 No. 4, pp. 323-347.

Crompton, J.L. (2004), "Motivations for pleasure vacations", in Williams, S. (Ed.), Tourism: Critical Concepts in the Social Sciences, Vol II the Experience of Tourism, Routledge, New York, NY, pp. 84-101.

Cronin, J.J., Jr, Brady, M.K. and Hult, G.T.M. (2000), "Assessing the effects of quality, value, and customer satisfaction on consumer behavioral intentions in service environments", Journal of Retailing, Vol. 76 No. 2, pp. 193-218.

Day, E. and Crask, M.R. (2000), "Value assessment: the antecedent of customer satisfaction", Journal of Consumer Satisfaction, Dissatisfaction and Complaining Behavior, Vol. 13, pp. 52-60.

Duman, T. and Mattila, A.S. (2005), "The role of affective factors on perceived cruise vacation value", Tourism Management, Vol. 26 No. 3, pp. 311-323.

Finley, K. (2013), “Trust in the sharing economy: an exploratory study”, Master thesis, The University of Warwick, Coventry.

Fishburn, P.C. (1968), "Utility theory”, Management Science, Vol. 14 No. 5, pp. 335-378.

Folger, J. (2016), "The pros and cons of using Airbnb”, available at: www.investopedia.com/articles/ personal-finance/032814/pros-and-cons-using-airbnb.asp?performancelayout=true (accessed 6 March 2016).

Forsythe, S. and Shi, B. (2003), "Consumer patronage and risk perceptions in internet shopping", Journal of Business Research, Vol. 56 No. 11, pp. 867-875.

Forsythe, S., Liu, C., Shannon, D. and Gardner, L.C. (2006), "Development of a scale to measure the perceived benefits and risks of online shopping", Journal of Interactive Marketing, Vol. 20 No. 2, pp. 55-75. 
APJIE 11,3

Gallarza, M.G. and Gil Saura, I. (2006), "Value dimensions, perceived value, satisfaction and loyalty: an investigation of university students' travel behaviour", Tourism Management, Vol. 27 No. 3, pp. 437-452.

Gallarza, M.G., Gil-Saura, I. and Holbrook, M.B. (2011), "The value of value: further excursions on the meaning and role of customer value", Journal of Consumer Behaviour, Vol. 10 No. 4, pp. 179-191.

Garner, S.J. (1986), "Perceived risk and information sources in services purchasing", The Mid-Atlantic Journal of Business, Vol. 24 No. 2, pp. 49-58.

Gutman, J. (1982), “A means-end chain model based on consumer categorization processes”, Journal of Marketing, Vol. 46 No. 2, pp. 60-72.

Guttentag, D. (2015), "Airbnb: disruptive innovation and the rise of an informal tourism accommodation sector", Current Issues in Tourism, Vol. 18 No. 12, pp. 1192-1217.

Hair, J.F., Ringle, C.M. and Sarstedt, M. (2011), "PLS-SEM: indeed a silver bullet”, Journal of Marketing Theory and Practice, Vol. 19 No. 2, pp. 139-151.

Han, H. and Hwang, J. (2013), "Multi-dimensions of the perceived benefits in a medical hotel and their roles in international travelers' decision-making process", International Journal of Hospitality Management, Vol. 35, pp. 100-108.

Hill, K. (2015), "After a woman was poisoned in an Airbnb, the company started giving out prevention devices", available at: http://fusion.net/story/229589/airbnb-death-safety-regulations/ (accessed 4 August 2016).

Hirschman, E.C. (1980), "Innovativeness, novelty seeking, and consumer creativity", Journal of Consumer Research, Vol. 7 No. 3, pp. 283-295.

Holbrook, M.B. and Hirschman, E.C. (1982), "The experiential aspects of consumption: consumer fantasies, feelings, and fun”, Journal of Consumer Research, Vol. 9 No. 2, pp. 132-140.

Horton, R.L. (1976), “The structure of perceived risk: some further progress”, Journal of the Academy of Marketing Science, Vol. 4 No. 4, pp. 694-706.

Iyer, B. (2014), "Airbnb builds its brand in Asia”, available at: www.campaignlive.com/article/airbnbbuilds-its-brand-asia/1320081 (accessed 8 July 2017).

Jacoby, J. and Kaplan, L.B. (1972), "The components of perceived risk", in Venkatesan, M. (Ed.), Proceedings of the 3rd Annual Conference of the Association for Consumer Research, Association for Consumer Research, Chicago, IL, pp. 382-393.

Jose, M.L. (2013), "First, listen to my story of being drugged on an Airbnb stay, then learn from it", available at: http://matadornetwork.com/trips/drugged-and-terrified-an-airbnb-booking-gonewrong/ (accessed 6 June 2016).

Kim, J.H., Ritchie, J.R.B. and McCormick, B. (2012), "Development of a scale to measure memorable tourism experiences", Journal of Travel Research, Vol. 51 No. 1, pp. $12-25$.

Kim, L.H., Qu, H. and Kim, D.J. (2009), "A study of perceived risk and risk reduction of purchasing airtickets online", Journal of Travel \& Tourism Marketing, Vol. 26 No. 3, pp. 203-224.

Kwun, J.-W. and Oh, H. (2004), "Effects of brand, price, and risk on customers' value perceptions and behavioral intentions in the restaurant industry", Journal of Hospitality \& Leisure Marketing, Vol. 11 No. 1, pp. 31-49.

Lai, A.W. (1995), "Consumer values, product benefits and customer value: a consumption behavior approach", in Kardes, F.R. and Sujan, M. (Eds), NA - Advances in Consumer Research 22, Association for Consumer Research, Provo, UT, pp. 381-388.

Lee, T.H. and Crompton, J. (1992), "Measuring novelty seeking in tourism", Annals of Tourism Research, Vol. 19 No. 4, pp. 732-751.

Lieber, R. (2015), “Airbnb horror story points to need for precautions”, available at: www.nytimes.com/ 2015/08/15/your-money/airbnb-horror-story-points-to-need-for-precautions.html?_r=1 (accessed 6 June 2016). 
Mimouni-Chaabane, A. and Volle, P. (2010), "Perceived benefits of loyalty programs: scale development and implications for relational strategies", Journal of Business Research, Vol. 63 No. 1, pp. 32-37.

Mitchell, V.W. and Greatorex, M. (1993), "Risk perception and reduction in the purchase of consumer services", The Service Industries Journal, Vol. 13 No. 4, pp. 179-200.

Antecedents of perceived value in Airbnb

Mun, J.M. (2013), "Online Collaborative Consumption: exploring Meanings, Motivations, Costs and Benefits", PhD dissertation, University of Minnesota, Minneapolis, MN.

Nikkei Asian Review (2016), “Airbnb use soars while Japan juggles legal conundrum”, available at: http://asia.nikkei.com/Business/Consumers/Airbnb-use-soars-while-Japan-juggleslegal-conundrum (accessed 8 July 2017).

Oh, H. (2000), "The effect of brand class, brand awareness, and price on customer value and behavioral intentions", Journal of Hospitality \& Tourism Research, Vol. 24 No. 2, pp. 136-162.

Otto, J.E. and Ritchie, J.R.B. (1996), “The service experience in tourism”, Tourism Management, Vol. 17 No. 3, pp. 165-174.

Pearson, P.H. (1970), "Relationships between global and specified measures of novelty seeking", Journal of Consulting and Clinical Psychology, Vol. 34 No. 2, pp. 199-204.

Petrick, J.F. (2002), “An examination of golf vacationers' novelty”, Annals of Tourism Research, Vol. 29 No. 2, pp. 384-400.

Petrick, J.F. (2004), "First timers' and repeaters' perceived value", Journal of Travel Research, Vol. 43 No. 1, pp. 29-38.

Pires, G., Stanton, J. and Eckford, A. (2004), "Influences on the perceived risk of purchasing online", Journal of Consumer Behaviour, Vol. 4 No. 2, pp. 118-131.

PricewaterhouseCoopers (2015), "Consumer intelligence series: the sharing economy", available at: www.pwc.com/us/en/industry/entertainment-media/publications/consumer-intelligence-series/ sharing-economy.html (accessed 4 July 2016).

Sanchez-Fernandez, R. and Iniesta-Bonillo, M.A. (2006), "Consumer perception of value: literature review and a new conceptual framework", Journal of Consumer Satisfaction, Dissatisfaction and Complaining Behavior, Vol. 19, pp. 40-58.

Satama, S. (2014), "Consumer adoption of access-based consumption services - case Airbnb”, Master thesis, Aalto University, Espoo.

Sonmez, S.F. and Graefe, A.R. (1998), "Determining future travel behavior from past travel experience and perceptions of risk and safety", Journal of Travel Research, Vol. 37 No. 2, pp. 172-177.

Sparks, B., Butcher, K. and Bradley, G. (2008), "Dimensions and correlates of consumer value: an application to the timeshare industry", International Journal of Hospitality Management, Vol. 27 No. 1, pp. 98-108.

Stone, R.N. and Grønhaug, K. (1993), "Perceived risk: further considerations for the marketing discipline”, European Journal of Marketing, Vol. 27 No. 3, pp. 39-50.

Stone, R.N. and Winter, F. (1985), "Risk in buyer behavior contexts: a clarification (BEBR Faculty", Working Paper No. 1216, University of Illinois Urbana Champaign, Champaign, IL.

Stone, Z. (2015), "Living and dying on Airbnb", available at: https://medium.com/matter/living-anddying-on-airbnb-6bff8d600c04\#.et84r3j9u (accessed 6 June 2016).

Sweeney, J.C. and Soutar, G.N. (2001), "Consumer perceived value: the development of a multiple item scale”, Journal of Retailing, Vol. 77 No. 2, pp. 203-220.

Sweeney, J.C., Soutar, G.N. and Johnson, L.W. (1999), "The role of perceived risk in the quality-value relationship: a study in a retail environment”, Journal of Retailing, Vol. 75 No. 1, pp. 77-105.

Ting, D. (2017), “Airbnb is becoming an even bigger threat to hotels says a new report”, available at: https://skift.com/2017/01/04/airbnb-is-becoming-an-even-bigger-threat-to-hotels-says-anew-report/ (accessed 3 May 2017). 
APJIE 11,3

Tussyadiah, I.P. (2016), "Factors of satisfaction and intention to use peer-to-peer accommodation", International Journal of Hospitality Management, Vol. 55, pp. 70-80.

Tussyadiah, I.P. and Pesonen, J. (2016), "Impacts of peer-to-peer accommodation use on travel patterns", Journal of Travel Research, Vol. 55 No. 8, pp. 1022-1040.

Verhage, J. (2016), “One Wall Street firm expects Airbnb to book a billion nights a year within a decade", available at: www.bloomberg.com/news/articles/2016-04-11/one-wall-street-firmexpects-airbnb-to-book-a-billion-nights-a-year-within-a-decade (accessed 13 September 2016).

Vogt, C. and Fesenmaier, D. (1998), "Expanding the functional information search", Annals of Tourism Research, Vol. 25 No. 3, pp. 551-578.

Williams, P. and Soutar, G.N. (2009), "Value, satisfaction and behavioral intentions in an adventure tourism context", Annals of Tourism Research, Vol. 36 No. 3, pp. 413-438.

Woodruff, R.B. (1997), "Customer value: the next source for competitive advantage", Journal of the Academy of Marketing Science, Vol. 25 No. 2, pp. 139-153.

Zauner, A., Koller, M. and Hatak, I. (2015), "Customer perceived value - conceptualization and avenues for future research", Cogent Psychology, Vol. 2 No. 1, pp. 1-17.

Zeithaml, V.A. (1988), "Consumer perceptions of price, quality, and value: a means-end model and synthesis of evidence", Journal of Marketing, Vol. 52 No. 3, pp. 2-22.

\section{Corresponding author}

Soo Hyun Jun can be contacted at: soohjun@kmu.ac.kr

For instructions on how to order reprints of this article, please visit our website: 